\title{
The Effect of Brand Perceptions on Repurchase When Using the E-Commerce Website for Shopping
}

\author{
Abbas N Albarq ${ }^{1}$ \\ ${ }^{1}$ School of Economics \& Administrative Science, Al Imam Muhammad ibn Saud Islamic University, Riyadh \\ 11431, Saudi Arabia \\ Correspondence: Abbas N Albarq, School School of Economics \& Administrative Science, Al Imam Muhammad \\ ibn Saud Islamic University, Riyadh 11431, Saudi Arabia. E-mail: dr.abbasalbarq@yahoo.com
}

Received: August 7, 2020

Accepted: November 18, 2020 Online Published: November 28, 2020

doi:10.5539/ijms.v12n4p93

URL: https://doi.org/10.5539/ijms.v12n4p93

\begin{abstract}
This study aims to investigate the influence of some critical factors (store/brand perceptions, and trust in the webstore) on online repurchase intention. A pre-validated questionnaire was distributed to a convenience sample with response rate of $95.2 \%(n=684)$ web-store buyers that were examined for assessing the research model. Primary data were collected during the period between December 2019 and February 2020, from respondents in Amman the capital of Jordan. Using AMOS 22.0 software, the collected data were analysed with structural equation modelling (SEM). Confirmatory factory analysis (CFA) was used to estimate the measurement model with respect to convergent and discriminant validities. This was followed by testing the structural model framework and research hypotheses. The results showed that retailers are able to increase trust in the web-store by carrying strong brands, and reap a number of benefits including image enhancement and pre-established demand, it has been found that the store as a brand could turn out to be as important that make it easier for customers to build trust, constituting a strong antecedent of behavioural intentions where behavioural intentions can lead to repurchase patterns. Unlike extant research, this study makes a novel contribution - to adduce evidence as per which both trust and intentions can have impact repurchase as far as web-stores are concerned. The relevancy can be explained with the fact that prior models were only found to have purchase intentions as the final dependent variable.
\end{abstract}

Keywords: store brand perception, trust, repurchase, SEM, Jordan

\section{Introduction}

The Internet is increasingly eliciting the attention of new e-commerce website endeavors as well as established retailers. E-commerce operations have spread their tentacles to cover all industries. The proliferation and expansion of e-commerce is taking place at a stunning pace. Statista (2018) suggests that global online retail sales would touch $\$ 4135$ billion by 2020 . Firms are continuing to make important investments in the internet market which is growing at a fast pace. A multi-channel environment provides firms with further channels to complete their purchase plans. Given the significant expansion in the uses of e-commerce, and the ever-greater dependence on it of businesses as well as consumers in the form of a significant mechanism of procurements and transactions, it is necessary to pinpoint factors which may allow online businesses to retain their competitive edge and satisfy their consumers.

This requires them to understand customer needs with regard to virtual services. In wake of their growing needs, consumers are increasingly seeking good quality services and products, improved service scopes, greater varieties and better customer services. For ensuring customer retention and retaining a competitive edge, firms are promulgating recognized brands (Aslam et al., 2018). This may cause marketers to relocate spend toward digital advertising that facilitates the path to purchase online. Hence, online marketers are required to prepare an online ecosystem in a manner that facilitate customer engagements (Dailey, 2004). Survival in today's competitive-commerce environment is important but fairly challenging where the competitor is only one click away. This implies that firms must seek ways of giving their customers a unique experience that encompasses a lot more than merely low prices.

Extant studies have examined facet that impact the adoption of e-commerce by furnishing sufficient proofs of challenges like breach of security/absence of payment systems and legal frameworks, the lack of government 
contribution and other issues such as payment (Al-dweeri et al., 2017). Albarq (2004) opine that recognized brands positively affect the value of online stores, which results in favorable purchase intention. Comprehensive stud ties and research has been undertaken on E-Quality and Brand Perceptions (Vásquez \& Vera-Martínez, 2020), trust (Albarq, 2006), and web satisfaction (Dailey, 2004). Despite worldwide growth of this channel and practical issues relating to e-commerce, many research areas that are significant to e-commerce operations continue to be unexplored. According to conclusive findings internal shopping values have an impact on shoppers' purchase behaviors.

Online shopping is still in the nascent stages in Jordan, which is a developing country in the Middle East that continues to confront several challenges relating to online shopping (Yaseen et al., 2016). Although there is an abundance of e-commerce websites across the country, online purchasing remains very low, according to Ministry of Information and Communications Technology (2016). Nevertheless, Alsoud and Othman (2018) stated that Jordan confronts many problems concerning online shopping since Jordanian customers remain cash-centric, which is why the number of online shoppers is decreasing each year. It is notable that the growth of online shoppers decreased to 8\% in 2015-2016 comparative to 14\% in 2011-2015 according to Al-dweeri et al. (2017). Jordan's Department of Statistics (2017) reported that Jordan's online shopping rate is only 4.8 percent. Al-dweeri et al. (2017) reported that several issues are plaguing to online shopping in the country, such as inaccurate information, unavailability products, long ordering process, unclear website content, and unavailability of alternative methods of delivery, inappropriate font size and inconsistent language. According to the Arab Advisor Group (2019), Jordan's e-commerce user base is 514,000, accounting for just $8.2 \%$ of its overall population.

Thus, several researchers have attempted to address the factors impacting online purchases in e-stores (Adwan et al., 2019; Alsoud \& Othman, 2018; Al-dweeri et al., 2017; Albarq, 2014). However, there is paucity of resources and information in the form of journals and articles about the prevalence of e-commerce services across Jordan, possibly due to fewer e-commerce activities. In the extant literature, there is lack of data on the pattern of purchase behaviors in the Middle East. Most researchers have focused on European nations or advanced economies such as the U.S. (Prashar et al., 2017; Alsoud \& Othman, 2018). Studies on Jordanian shoppers' motives for buying remain limited in terms of web merchandising. All these factors make it necessary to conduct empirical studies for determining several antecedent factors along with their importance in impacting Jordanian shoppers' web purchase intentions.

The present study is aimed at improving the understanding of the factors behind behavioral intentions as well as repurchasing in a web-store. These are inclusive of product and store brand perceptions, and customer trust. Thus, a conceptual framework for an explanatory model has been put forward to account for the hypothesized relationships between these constructs, thereby lending credence to the model. Apart from supporting this proposed model, to the current study is aimed at addressing three gaps in the research literature on web-store consumer behavior in a developing country such as Jordan: 1) the effect of store brand perception on trust as well as behavioral intentions; 2) the impact of product brand perception on trust and behavioral intentions; and 3) the effect of trust and behavioral intentions on customers' repurchase patterns.

Moreover, no attempt has been made in prior studies to adopt a multi-item approach for enhancing the validity and reliability of repurchase pattern measurement, assessing it as a dimension as opposed to a single-item variable. In this regard, an empirical study carried out by Diamantopoulos et al. (2012) pointed out that a multi-item scale is more likely to be a valid and stable measurement technique as compared to a single item measurement to assess a specific construct. This is attributed to the multiple cross-confirmation between various pointers for a given latent variable. Therefore, a structural equation model was developed with data gathered from a sample of web-store shoppers to test this model and its supporting hypotheses empirically.

\section{Literature Review}

This section entails the presentation of main definitions and concepts that have been used in the study. Previous work has been reviewed and our research model and hypotheses are put forward in this section. A conceptual framework is developed that connects the hypotheses supporting the model schematized in Figure 1. Definitions of the constructs that are involved in this model are depicted in Table 1 for the current study. 
Table 1. Latent variable definition

\begin{tabular}{|c|c|c|}
\hline Latent Variable & Definition & Adapted from \\
\hline Store brand perception & $\begin{array}{l}\text { Cognitive associations with the name and logo of the store with the promise } \\
\text { of delivery based on reputation and previous experience as indication of } \\
\text { quality and value added. }\end{array}$ & $\begin{array}{l}\text { Horppu et al., 2008; Rezaei \& } \\
\text { Amin, } 2013\end{array}$ \\
\hline $\begin{array}{l}\text { Product brand } \\
\text { perception }\end{array}$ & $\begin{array}{l}\text { Cognitive associations with the brands of the products that are offered with } \\
\text { promises of fulfilment based on reputation and previous experiences }\end{array}$ & $\begin{array}{l}\text { Parasuraman \& Grewal, 2000; } \\
\text { Keller, } 2005\end{array}$ \\
\hline Trust in the webstore & $\begin{array}{l}\text { Consumer perception that service providers can be depended upon for } \\
\text { keeping their promises. }\end{array}$ & $\begin{array}{l}\text { Amin et al., 2014; Rezaei \& } \\
\text { Amin, } 2013\end{array}$ \\
\hline Behavioural intentions & $\begin{array}{l}\text { Commitment on the part of consumers to consistently purchase a brand; in } \\
\text { this case, to visit a brand store, on account of a personal preference. }\end{array}$ & $\begin{array}{l}\text { Flavián et al., 2006; Connolly } \\
\text { \& Bannister, } 2007\end{array}$ \\
\hline Repurchase pattern & $\begin{array}{l}\text { The actual purchase rate or frequency of purchasing behavior or even } \\
\text { repurchase of a given brand within a particular category (in this case within } \\
\text { the same store brand). }\end{array}$ & $\begin{array}{l}\text { Voss et al., 2010; Seiders et al., } \\
2005\end{array}$ \\
\hline
\end{tabular}

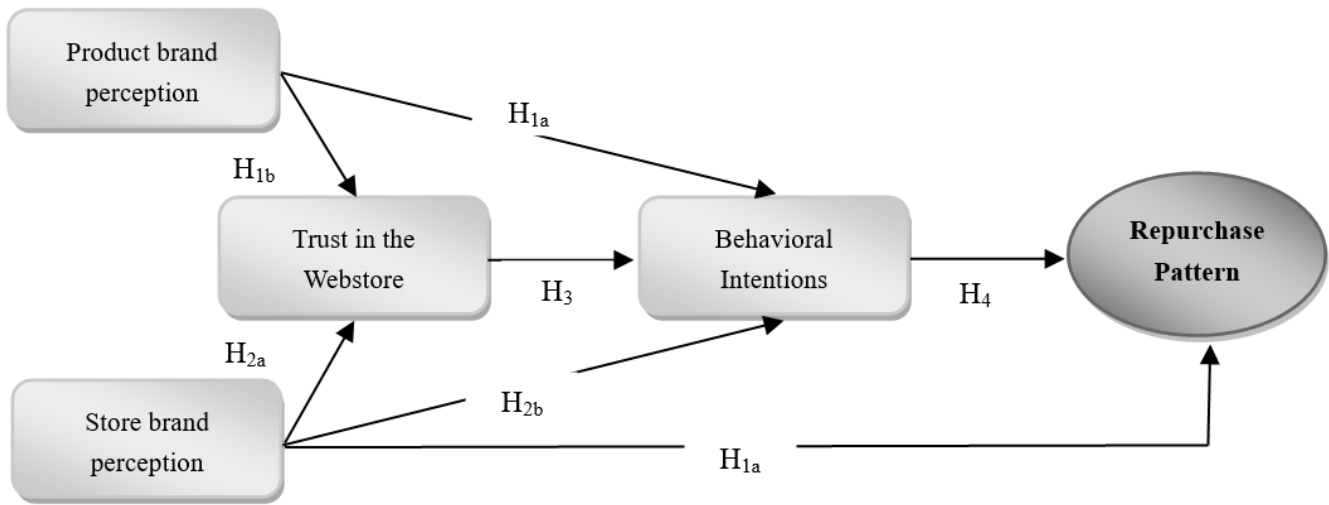

Figure 1. Conceptual framework and hypotheses

\subsection{The Influences of Product Brand Perception on Trust and Behavioral Intention}

Since customers that make purchases via a website lack the element of personal contact with a retailer, they may be compelled to depend on offered brands (Gehrt \& Yan, 2004). At the same time, it is possible that some product brands could invoke such levels of trust within the customer that it is possible for a spill-over effect to take place, thus providing benefits both to the retailer and its website (Zboja \& Voorhees, 2006). Retailers can benefit from this association by creating a connection with their consumers using the brands they are associated with. Therefore, retailers would do well to bolster customer perception of the brands that are offered by them (Zboja \& Voorhees, 2006). By collaborating with each other, retailers and manufacturers can benefit from each other's brands (Webster, 2000). By increasing trust in the web-store by carrying strong brands (Zboja \& Voorhees, 2006), retailers may be able to reap several benefits, including pre-established demand and image enhancement (Webster, 2000). Hence, we arrive at the following hypothesis:

H1a: Product brand perception positively impacts consumer trust in a web-store.

H1b: Product brand perception positively impacts behavioral intentions in a web-store.

\subsection{The Influences of Brand Store Perception on Trust and Behavioral Intention}

While the product catalogue plays a significant role, it has been found that the store as a brand could assume as much significance, if not more. The store's corporate image refers to combining the store as a brand using the manufacturer brands that the store offers (Parasuraman \& Grewal, 2000). Store image refers to a store's impression to create a definite perception among customers. Brand store perception is referred to brand associations that have a strong resonance with consumers' mind space. Brand associations deal with the perceived benefits of consumers or perceptions relating to the store's characteristic (Beristain \& Zorrilla, 2011). Dimensions of store image are based on factors like the variety/quality of products, their prices, the store's physical facilities, as well as the offerings made by sales staff (Beristain \& Zorrilla, 2011). Thus, quality services help maintain customer satisfaction and assumes great significant for competitive edge (Parasuraman \& Grewal, 2000). 
A positive online store image favors customer satisfaction and store loyalty (Bloemer \& DeRuyter, 1998). A favourable brand image tends to have a positive effect on relevant outcomes, such as premium price capability and positive word-of-mouth (Bloemer \& DeRuyter, 1998; Vásquez \& Vera-Martínez, 2020). In the context of clothing markets, customers tend to be sensitive to store brand personality, thus suggesting that the store's image can indeed make a difference (Diamantopoulos et al., 2012). Thus, a strong store image offering recognition, familiarity, confidence and other associations that make it easier for customers to build trust.

Therefore:

$\boldsymbol{H} 2 \boldsymbol{a}$ : Brand store perception positively impacts customer trust in a web-store.

$\boldsymbol{H} \boldsymbol{2 b}$ : Brand store perception positively impacts behavioral intentions in a web-store.

\subsection{The Influences of Trust in Intention and Repurchase}

According to $\mathrm{Lu}$, Zeng and Fan (2016), when people are keen to take part in activities relating to e-commerce, they are required to expect a higher degree of ambiguity and risk pertaining to other parties' opportunistic behavior, which denotes e-commerce providers in this context. Such perceptions that are negative in nature deter potential customers from taking part in web transactions ( $\mathrm{Lu}$ et al., 2016). To that end, the social mechanism of trust appears is reported to lower any vulnerability felt by potential customers in terms of e-commerce (Harrison-Walker, 2001). Indeed, trust is an important social behavior perquisite, particularly in terms of significant processes of decision-making (Hidayanto et al., 2014).

In a relationship, it also signifies an important risk predictor, which implies taking the leap of faith of making online purchases (Nurizka, 2019). Trust would eventually increase a person's willingness to remain susceptible to someone else's opportunistic traits, thus lowering perceptions of risks (Lu et al., 2016). Trust is applicable to both products and vendors int he realm of e- commerce (Devaraj et al., 2002). Trust of vendors refers to the extent of trust customers have in the service provided by e-commerce provider. In the context of this study, trust in web-stores is inclusive of incorporating security elements, guaranteeing confidentiality and conveying a reliable image (Nurizka, 2019). The lack of confidence caused by the absence of security and privacy is regarded as a major impediment in obtaining online commerce development (Long \& McMellon, 2004). Confidence in online buyers are reinforced by the ability of online sellers to assess as well as fulfil customer needs and expectations (Giannakopoulos et al., 2014). In other words, online customers prefer to make their purchases from the websites that they trust (Vásquez \& Vera-Martínez, 2020). This is attributed to the fact that trust can go a long way in lowering buyer uncertainty (Angriawan \& Thakur, 2008). Therefore, trust tends to encourage loyalty in an Internet environment (Jiang et al., 2008), thereby constituting a stronger antecedent of behavioral intentions than other variables, such as customer-perceived value and perceived price level (Nurizka, 2019).

H3a: Trust in a web-store positively impacts behavioral intentions.

$\boldsymbol{H} \boldsymbol{3} \boldsymbol{b}$ : Trust in a web-store positively impacts repurchase patterns.

\subsection{The Influences of Behavioral Intentions on Repurchase}

The concept of repurchase is becoming increasingly popular among marketing philosophers. Hellier, Geursen, Carr and Rickard (2003) have defined repurchase as "the individual's decision about buying again a designated service from the same company, taking into accounts his or her present situation and likely circumstances". With regard to the existing study, the focus is on both intention and repurchase behavior. Intention denotes the ability to predict someone's behavior that he has control over. Intention is observed to have a considerable correlation with volitional behavior, which is known to be a behavior that one can choose 'at will' to execute or not execute (Nurizka, 2019). Albarq (2014) defines online repurchases as a subjective probability that experienced shoppers will make repeatedly from the same online retailer. It is very important to investigate the reasons why consumers remain faithful to a particular online retailer. The cost of retaining experienced consumers is less than the cost of attracting and acquiring new clients (Lim \& Cham, 2015) which means that online vendors can augment their profits by focusing more on motivating their experienced customers in order to make repeat purchases.

It has been observed that customers do not always buy from stores offering the lowest price (Reichheld \& Schefter, 2000). They also consider other elements like efforts and time while making purchase decisions. Customer retention and repeating buyers are sources of profit because loyal customers are likely to be less sensitive to price, and are more likely to make positive recommendations so as to spread the word (Vásquez \& Vera-Martínez, 2020). Given that convenience in Internet shopping is predicated on time and effort involved, customers tend to make repurchase decisions based on factors such as ewer hassles and time savings, particularly for routine repurchase items. Repurchase behavior is regarded as an objectively observed indicator (Seiders et al., 2005). Repurchase has been proposed as a valid measurement of store loyalty (Lim \& Cham, 2015). According 
to extant literature, behavioral intentions and perceived value can pave the way to repurchase patterns (Vásquez \& Vera-Martínez, 2020; Seiders et al., 2005). Thus, it can be inferred that behavioral intentions have been established as an antecedent of actual repurchase. Hence, the following hypothesis is arrived at:

H4: Behavioral intentions in a web-store have a positive effect on the repurchase patterns of consumers.

\section{Method}

\subsection{Survey Instruments}

The implementation of a post-hoc study entailed the designing of a structured questionnaire. In this study, there were two parts assigned to an instrument. The first comprised of respondents 'gender, age, educational qualifications, as well as purchasers. The second part encompassed the statements obtained from the variables constituting the research model. To that end, five variables from current empirical studies were used to develop survey instruments. Identification of five constructs was made after carrying out an extensive literature review, whose operationalization was done through referring to existing studies to produce validated reflective scales. Arabian lecturers were requested to translate the questionnaire to Arabic from English since this survey was carried out in Jordan.

For all constructs, the measurement items were determined and presented before a four-member expert group - one from a marketing company and three academicians from Jordanian university. After examining the aptness of constructs, a set of 17 statements was chosen to encapsulate the most recent constructs. The sources, number of items and variables are shown by Table 2. The study used a Likert scale for measuring the chosen items/variables, with (1) denoting disagree and (7) referring to strongly agree. After piloting the instrument among 36 respondents, the instrument was finalized after making slight language-related changes.

Table 2. Variables, no. of items and sources and recent validation

\begin{tabular}{lll}
\hline Variable & No. of Item & Items Source \\
\hline Trust on the web-store & 3 & Hidayanto et al., 2014 \\
Products brand perception & 3 & Vásquez and Vera-Martínez, 2020 \\
Brand store perception & 3 & Vásquez and Vera-Martínez, 2020 \\
Behavioural intentions & 4 & Albarq, 2014 \\
Repurchase Intention & 4 & Aslam et al., 2018 \\
\hline
\end{tabular}

\subsection{Data Collection/Sample}

Collection of primary data was premised on convenience sampling due to the ease of volunteering as well as because of their availability and easy access, via which data was gathered between December 2019 and February, 2020 from respondents in Amman, the capital city of Jordan. The respondents were more than 20 years old who were experienced in online shopping. A web Google form was used to collect the responses and the questionnaire's hard copy was used to distribute to the respondents who were contacted in universities, malls, and hopping restaurants of Aman. Before being handed over with the questionnaire, they were asked whether they would like to make online purchases or held a minimum of one credit card. This study did not take business-to-business buyers into consideration. Those who did not shop online were not considered to be a respondent which is why, they were not provided with a questionnaire to fill out. Thus, a convenience sample comprising of 718 respondents was collected. Nevertheless, in many cases, the invitation was forwarded from respondent to respondent, which involved some loss of control over the process. Therefore, a verification of participants was conducted wherein the sample was scaled down to 684 observations that met the above-mentioned features

\subsection{Analysis}

AMOS 20.0 software was used to perform data analysis via structural modelling (SEM). The two-step data analysis approach proposed by Hair et al. (2013) was adopted. Confirmatory factory analysis (CFA) was performed for gauging the measurement modeling terms of discriminant and convergent validities. Thereafter, the research hypotheses and structural model framework were tested.

\section{Results}

Table 3 depicts the respondents' demographic traits. This information can be useful in facilitating an improved understanding on the respondents' profiles under investigation. 
Table 3. Demographic profile of respondents

\begin{tabular}{llll}
\hline Demographic Group & Demographic Category & Count & Percentage \\
\hline Gender & Male & 288 & 42.1 \\
Age & Female & 396 & 57.9 \\
\multirow{3}{*}{ Marital Status } & $22-39$ & 456 & 66.7 \\
& $40-59$ years & 228 & 33.3 \\
Education level & Married & 391 & 57.1 \\
& Single & 293 & 45.5 \\
& other & 18 & 2.6 \\
Monthly Income & Schooling & 0 & 0.0 \\
& Graduation & 407 & 59.5 \\
& Post-graduation \& above & 277 & 40.5 \\
& Less than 600 JOD & 4 & 0.6 \\
Purchasers by web-store & 600 to 1499 JOD & 411 & 60.1 \\
& 1500 to 2499 JOD & 238 & 34.8 \\
& More than 2500 JOD & 31 & 4.5 \\
& Amazon & 103 & 15.1 \\
& Matjarii & 19 & 2.8 \\
& Cash Basha & 12 & 1.8 \\
& Amman Cart & 31 & 4.6 \\
& SHEIN & 48 & 7.1 \\
& Ubay & 37 & 5.4 \\
& Other Local web stores & 160 & 23.4 \\
& Other international web stores & 274 & 39.8 \\
\hline
\end{tabular}

Nearly $42.1 \%$ of respondents are accounted for by males (288) while females represent $57.9 \%$ (396). At the time of conducting this research, the majority of respondents were 22-39 years old (66.7\%) and were married (57.1\%). In addition, demographic information concerning level of income or monthly allowance were also collected to indicate the respondents' purchasing power. The majority of them were found to be in the range of 600-1499 JOD, accounting for $61.1 \%$ of all respondents. Purchasers made via web-stores in Jordan included the following: Amazon 15.1\%, SHEIN 7.1\%, Ubay 5.4\%, Matjarii 2.8\%, Cash Basha 1.8\%, other international web store $39.8 \%$ and other local web stores $23.4 \%$.

Table 4. Measurement model

\begin{tabular}{|c|c|c|c|c|c|}
\hline Factors and Items & Factor Loading & CR & $\alpha$ & AVE & Construct Reliability \\
\hline Trust on the web-store & & & 0.87 & 0.62 & 0.87 \\
\hline This web-store protects my credit card details & 0.801 & 10.871 & & & \\
\hline I feel secure in the transactions I make in this web-store & 0.776 & 10.563 & & & \\
\hline This web-store protects my privacy & 0.831 & 11.248 & & & \\
\hline Products brand perception & & & 0.84 & 0.55 & 0.83 \\
\hline This web-store offers products from well-known brands & 0.626 & Fixed & & & \\
\hline This web-store offers products from leading brands & 0.657 & 10.499 & & & \\
\hline This web-store offers reliable brand products & 0.845 & 9.035 & & & \\
\hline Brand store perception & & & 0.92 & 0.74 & 0.92 \\
\hline The brand of this web-store has a good reputation & 0.806 & 13.577 & & & \\
\hline The brand of this web-store is recognized & 0.906 & 16.345 & & & \\
\hline The brand of this web-store is reliable & 0.895 & 16.025 & & & \\
\hline Behavioural intentions & & & 0.92 & 0.74 & 0.92 \\
\hline If I had to, I would buy again from this online store & 0.806 & 13.577 & & & \\
\hline I would use this online store again to meet my needs & 0.906 & 16.35 & & & \\
\hline For future purchases this online store is recommendable & 0.895 & 16.025 & & & \\
\hline I will buy again from this online store & 0.832 & Fixed & & & \\
\hline Repurchase pattern & & & 0.88 & 0.58 & 0.87 \\
\hline I buy frequently from this web store & 0.782 & Fixed & & & \\
\hline I will purchase apparel products from this web store & 0.759 & 10.970 & & & \\
\hline $\begin{array}{l}\text { I will buy selected brand when I next require an apparel from } \\
\text { this online store }\end{array}$ & 0.195 & Deleted & & & \\
\hline I will recommend this web store to my friends & 0.719 & 10.558 & & & \\
\hline I will spread positive word-of-mouth about the web store & 0.789 & 11.665 & & & \\
\hline
\end{tabular}


In order to determine the parameter estimates' appropriateness and ascertain the proposed model's adequacy in its entirety, evaluation was performed. As per goodness-of-fit statistics, the model was observed to be appropriate. As shown in Table 4, the ratio of chi square minimum to the degree of freedom (CMIN/df) was 1.049. This indicated a good level of agreement between the data and the hypothesized model. This study revealed the following values: IFI $(=0.968)$, GFI $(=0.940)$, adjusted GFI $(=0.929)$, CFI $(=0.999)$, normed fit index $(\mathrm{NFI})(=0.975)$, RMSEA $(=0.011)$ and TLI $(=0.999)$. The parameter estimates' statistical significance was determined as test-statistic t. Since the values are high for all cases, convergent validity is indicated. The below table shows the measurement model, standardized loadings, and accompanying $t$ values (or what is alluded to as critical ratios).

In Table 5, as per Farrell (2010), when a high correlation exists between a specific construct's measures or that which is corelated with other constructs, the AVE's square root for a particular construct is noted to exceed the absolute value of the given construct's standardized correlation with other construct that finds mention in the analysis $\left[\right.$ AVE $>$ correlation $\left.{ }^{2}\right]$.

Table 5. Discriminant validity for the measurement model

\begin{tabular}{llllll}
\hline Construct & PBP & BSP & TWS & BI & RP \\
\hline Products brand perception (PBP) & $\mathbf{0 . 8 6 0 *}$ & & & & \\
Brand store perception (BSP) & 0.540 & $\mathbf{0 . 8 2 4}$ & & & \\
Trust on the web-store (TWS) & 0.646 & 0.560 & $\mathbf{0 . 7 6 1 *}$ & & \\
Behavioural intentions (BI) & 0.676 & 0.595 & 0.703 & $\mathbf{0 . 8 6 6 *}$ & \\
Repurchase pattern (RP) & 0.460 & 0.463 & 0.611 & 0.625 & $\mathbf{0 . 7 5 4 *}$ \\
\hline
\end{tabular}

Structural Model Analysis: In order to examine the research model, SEM testing (hypothetical) with MLE (maximum likelihood estimation) was utilized. Thereafter, the testing of two endogenous variables and five exogenous variables was done to determine the proposed model's strength along with the aforementioned hypotheses. The proposed model's overall fit indices were determined in the following manner: Chi-square = 382.041; Degree of Freedom $=340 ; \mathrm{CMIN} / \mathrm{df}=1.124 ; \mathrm{CFI}=0.997$; GFI $=0.936 ;$ AGFI $=0.923 ; \mathrm{NFI}=0.973$; TLI $=0.997$; RMSEA $=0.018$. Very good fit was observed between the data and the planned model, thus indicating that the model was sound and could offer a sound basis to test the hypothesized paths. Table 6 depicts all of these details. Findings of the structural model that lent support to four hypotheses have been put forward.

Table 6. Structural model results

\begin{tabular}{|c|c|c|c|c|}
\hline Hypothesis & Estimate $\beta$ & t-value & $\mathbf{p} \leq$ & Result \\
\hline H1a: Products brand perception-Trust on the web-store & 0.16 & 2.75 & 0.006 & Accepted \\
\hline H1b: Products brand perception-Behavioral intentions & 0.23 & 2.55 & 0.001 & Accepted \\
\hline H2a: Brand store perception-Trust on the web-store & 0.32 & 4.63 & 0.001 & Accepted \\
\hline H2b: Brand store perception-Behavioral intentions & 0.18 & 3.34 & 0.001 & Accepted \\
\hline H3a: Trust on the web-store-Behavioral intentions & 0.35 & 4.12 & 0.001 & Accepted \\
\hline H3b: Trust on the web-store-Repurchase pattern & 0.37 & 4.78 & 0.001 & Accepted \\
\hline H4: Behavioral intentions-Repurchase pattern & 0.39 & 4.97 & 0.001 & Accepted \\
\hline
\end{tabular}

Note. Chi-square $=382.041 ;$ Degree of Freedom $=340 ; \mathrm{CMIN} / \mathrm{df}=1.124 ; \mathrm{CFI}=0.997 ; \mathrm{GFI}=0.936 ; \mathrm{AGFI}=0.923 ; \mathrm{NFI}=0.973 ; \mathrm{TLI}=$ $0.997 ; \operatorname{RMSEA}=0.018 ; * * * \mathrm{p}<0.001$ and $* * \mathrm{p}<0.01$

\section{Discussion and Conclusion}

Results derived as a result of the article provide some actionable insights into the significant perspectives pertaining to product and store perceptions, the element of trust reposed in online stores, behavioral intentions as well as outlining new patterns for repurchasing. This study makes significant contribution to the prevailing information on online buying behavior and e-retailing, particularly those who have both practical and theoretical interest in an emerging market such as Jordan. In addition, it posits these factors' influences (exogenous latent) as endogenous latent on the repurchase pattern.

Product brand perception refers to the manner in which a customer tends to examine the quality of a web-store's the product catalogue. According to the literature review undertaken by this study, very little scholarly attention has been paid to the perception on web-store product brands. Considering the current findings, it is not farfetched to suggest that the perception of web-store product brand is expected to have a direct impact on trust that is 
congruent with what was previously observed for physical stores. On the one hand there are various product brands; on the other hand, there is the name of the web-store. The attractiveness of store as a brand is reported to be closely linked to three factors: the store's association with its customers, the experience of shopping in the store and the effectiveness with which the store understands its customers, which is evidenced by the selection offered by it (Dennis et al., 2007). For this reason, the current study claims that store brand perceptions can directly impact trust and behavioral intentions on the web-store, as per Basu (2016), and Loureiro et al. (2014). As far as trust in the web-store is concerned, it was found to be directly correlated with behavioral intentions towards a web-store, as observed by Chaudhuri and Holbrook (2001), and Loureiro et al. (2014).

Furthermore, linking brand store perceptions to trust and repurchase in a web-store context is found to have a pertinent managerial implication. This is because risk averse customers have a proclivity to brand be loyal towards for a brand for a longer period of time (Basu, 2016). At the same time, a set of robust and enduring brand perceptions linked to the identity of the web-store can help augment customer trust. Therefore, building these can catalyze the attraction of risk-averse customers, who, in turn, offer a better chance of developing a long-term relationship with long-term repurchase patterns.

This study also makes a novel contribution - to adduce evidence as per which both trust and intentions can have impact repurchase as far as web-stores are concerned. The relevancy can be explained with the fact that prior models were only found to have purchase intentions as the final dependent variable. Purchase intentions signify an attitudinal measurement, albeit not a measurement of an actual observable behavior. In a study that was carried out by Nisar and Prabhakar (2017), elements of a web-store were found to have a positive correlation with actual behavior, such as client expenditure, as opposed to actual repurchase patterns. As mentioned before, it has been confirmed in a recent meta-analysis (Kim \& Peterson, 2017). Connecting the entire model to action loyalty's measurements as a final dependent variable has high pertinence, both theoretically and practically.

Although this research attempted to draw some conclusions on Jordan, it suffers from some limitations that must be addressed in future studies. Here, it must be mentioned that no specific product categories were required for participating in the study. For this reason, it is suggested that future research studies must emphasize on specific product categories in order to deepen the knowledge of how involvement with specific categories of product impacts web-store perception. Additionally, testing these models with specific product category may go a long way in reducing statistical variability, thereby enhancing the statistical associations between different variables. As mentioned above, considering the fact that this is the first-time store brand perception finds inclusion in a model to elucidate loyalty or make repurchases in a web-store, we took a decision to include it as an exogenous variable in the model. In particular, we did not wish to address the question of the manner in which web-store brand perception is constructed because of its intrinsic complexities. Moreover, it would take the focus away from the model's original objective and the goals that this study aims to accomplish. However, it must be pointed out that web-store quality and product brand perception, among several other factors, can indeed have an impact on the perception of web-store brands. It is for this reason that we believe this holds a very interesting path for future research.

\section{Acknowledgements}

The author would like to thank the respondents who participated in this study for taken the time to fill in the questionnaire.

\section{References}

Al-Adwan, A. S., Alrousan, M., Al-Soud, A., \& Al-Yaseen, H. (2019). Revealing the black box of shifting from electronic commerce to mobile commerce: The case of Jordan. Journal of Theoretical and Applied Electronic Commerce Research, 14(1), 51-67. https://doi.org/10.4067/S0718-18762019000100105

Al-dweeri, R. M., Obeidat, Z. M., Al-dwiry, M. A., Alshurideh, M. T., \& Alhorani, A. M. (2017). The impact of e-service quality and e-loyalty on online shopping: moderating effect of e-satisfaction and e-trust. International Journal of Marketing Studies, 9(2), 92-103. https://doi.org/10.5539/ijms.v9n2p92

Albarq, A. N. (2006). Intention to shop online among university students in Jordan. Doctoral dissertation, Graduate School, Universiti Utara Malaysia.

Albarq, A. N. (2014). Measuring the impacts of online word-of-mouth on tourists' attitude and intentions to visit Jordan: An empirical study. International Business Research, 7(1), 14. https://doi.org/10.5539/ibr.v7n1p14

Alsoud, M. A. S., \& bin Lebai Othman, I. (2018). The Determinant of Online Shopping Intention in Jordan: A Review and Suggestions for Future Research. International Journal of Academic Research in Business and Social Sciences, 8(8), 441-457. https://doi.org/10.6007/IJARBSS/v8-i8/4507 
Amin, M., Rezaei, S., \& Abolghasemi, M. (2014). User satisfaction with mobile websites: The impact of perceived usefulness (PU), perceived ease of use (PEOU) and trust. Nankai Business Review International, 5, 258-274. https://doi.org/10.1108/NBRI-01-2014-0005

Angriawan, A., \& Thakur, R. (2008). A parsimonious model of the antecedents and consequence of online trust: An uncertainty perspective. Journal of Internet Commerce, 7(1), 74-94. https://doi.org/10.1080/15332860802004337

Arab Advisor Group. (2019). Jordan internet users and e-commerce survey 2019. Retrieved July 7, 2019, from http://www.arabadvisors.com/update-jordan\%E2\%80\%99s-cellular-market-end-march-2019

Aslam, W., Ham, M., \& Farhat, K. (2018). Influencing factors of brand perception on consumers' repurchase intention: An examination of online apparel shopping. Management: Journal of Contemporary Management Issues, 23(2), 87-102. https://doi.org/10.30924/mjcmi/2018.23.2.87

Basu, K. (2000). E-Branding or Re-Branding? The Impact of E-Business on Global Branding Strategies. In L. P. Willcocks \& C. Sauer (Eds.), Moving to E Business: The Ultimate Practical Guide to Effective E-business. Century. ISBN 978-0712669832.

Beristain, J. J., \& Zorrilla, P. (2011). The relationship between store image and store brand equity: A conceptual framework and evidence from hypermarkets. Journal of Retailing and Consumer Services, 18(6), 562-574. https://doi.org/10.1016/j.jretconser.2011.08.005

Bloemer, J., \& De Ruyter, K. (1998). On the relationship between store image, store satisfaction and store loyalty. European Journal of Marketing, 32, 499-513. https://doi.org/10.1108/03090569810216118

Chaudhuri, A., \& Holbrook, M. B. (2001). The chain of effects from brand trust and brand affect to brand performance: The role of brand loyalty. Journal of Marketing, 65(2), 81-93. https://doi.org/10.1509/jmkg.65.2.81.18255

Connolly, R., \& Bannister, F. (2007). Consumer trust in Internet shopping in Ireland: towards the development of a more effective trust measurement instrument. Journal of Information Technology, 22(2), 102-118. https://doi.org/10.1057/palgrave.jit.2000071

Dailey, L. (2004). Navigational web atmospherics: Explaining the influence of restrictive navigation cues. Journal of Business Research, 57(7), 795-803. https://doi.org/10.1016/S0148-2963(02)00364-8

Dennis, C., King, T., \& Martenson, R. (2007). Corporate brand image, satisfaction and store loyalty. International Journal of Retail \& Distribution Management, 35, 544-555. https://doi.org/10.1108/09590550710755921

Devaraj, S., Fan, M., \& Kohli, R. (2002). Antecedents of B2C channel satisfaction and preference: Validating e-commerce metrics. Information Systems Research, 13(3), 316-333. https://doi.org/10.1287/isre.13.3.316.77

Diamantopoulos, A., Sarstedt, M., Fuchs, C., Wilczynski, P., \& Kaiser, S. (2012). Guidelines for choosing between multi-item and single-item scales for construct measurement: A predictive validity perspective. Journal of the Academy of Marketing Science, 40(3), 434-449. https://doi.org/10.1007/s11747-011-0300-3

Flavián, C., Guinalíu, M., \& Gurrea, R. (2006). The role played by perceived usability, satisfaction and consumer trust on website loyalty. Information \& Management, 43(1), 1-14. https://doi.org/10.1016/j.im.2005.01.002

Gehrt, K. C., \& Yan, R. N. (2004). Situational, consumer, and retailer factors affecting Internet, catalog, and store shopping. International Journal of Retail \& Distribution Management, 32, 5-18. https://doi.org/10.1108/09590550410515515

Giannakopoulos, G., Sakas, D., Vos, A., Marinagi, C., Trivellas, P., Eberhagen, N., \& Skourlas, C. (2014). Electronic service quality in online shopping and risk reduction strategies. Journal of Systems and Information Technology, 16, 170-186. https://doi.org/10.1108/JSIT-01-2014-0008

Hair, J. F., Ringle, C. M., \& Sarstedt, M. (2013). Partial least squares structural equation modeling: Rigorous applications, better results and higher acceptance. Long Range Planning, 46(1-2), 1-12. https://doi.org/10.1016/j.lrp.2013.01.001

Harrison-Walker, L. J. (2001). The measurement of word-of-mouth communication and an investigation of service quality and customer commitment as potential antecedents. Journal of Service Research, 4(1), 60-75. https://doi.org/10.1177/109467050141006 
Hellier, P. K., Geursen, G. M., Carr, R. A., \& Rickard, J. A. (2003). Customer repurchase intention. European Journal of Marketing, 37, 1762-1800. https://doi.org/10.1108/03090560310495456

Hidayanto, A. N., Herbowo, A., Budi, N. F. A., \& Sucahyo, Y. G. (2014). Determinant of customer trust on e-commerce and its impact to purchase and word of mouth intention: A case of Indonesia. Journal of Computer Science, 10(12), 2395-2407. https://doi.org/10.3844/jcssp.2014.2395.2407

Horppu, M., Kuivalainen, O., Tarkiainen, A., \& Ellonen, H. K. (2008). Online satisfaction, trust and loyalty, and the impact of the offline parent brand. Journal of Product \& Brand Management, 17, 403-413. https://doi.org/10.1108/10610420810904149

Jiang, P., Jones, D. B., \& Javie, S. (2008). How third - party certification programs relate to consumer trust in online transactions: An exploratory study. Psychology \& Marketing, 25(9), 839-858. https://doi.org/10.1002/mar.20243

Keller, K. L. (2005). Choosing the right brand elements and leveraging secondary associations will help marketers build brand equity. Marketing Management, 14(5), 19-23.

Kim, Y., \& Peterson, R. A. (2017). A Meta-analysis of Online Trust Relationships in E-commerce. Journal of Interactive Marketing, 38, 44-54. https://doi.org/10.1016/j.intmar.2017.01.001

Lim, Y. M., \& Cham, T. H. (2015). A profile of the Internet shoppers: Evidence from nine countries. Telematics and Informatics, 32(2), 344-354. https://doi.org/10.1016/j.tele.2014.10.002

Long, M., \& McMellon, C. (2004). Exploring the determinants of retail service quality on the Internet. Journal of Services Marketing, 18, 78-90. https://doi.org/10.1108/08876040410520726

Loureiro, S. M. C., Miranda, F. J., \& Breazeale, M. (2014). Who needs delight? Journal of Service Management, 25, 101-124. https://doi.org/10.1108/JOSM-06-2012-0106

Lu, B., Zeng, Q., \& Fan, W. (2016). Examining macro-sources of institution-based trust in social commerce marketplaces: An empirical study. Electronic Commerce Research and Applications, 20, 116-131. https://doi.org/10.1016/j.elerap.2016.10.004

Nisar, T. M., \& Prabhakar, G. (2017). What factors determine e-satisfaction and consumer spending in e-commerce retailing? Journal of Retailing and Consumer Services, 39, 135-144. https://doi.org/10.1016/j.jretconser.2017.07.010

Nurizka, M. A. (2019). Hubungan Antara Konformitas Dengan Perilaku Konsumtif Produk Make Up Pada Siswi Sma Negeri 2 Medan. Doctoral dissertation, Universitas Medan Area.

Parasuraman, A., \& Grewal, D. (2000). The impact of technology on the quality-value-loyalty chain: A research agenda. Journal of the Academy of Marketing Science, 28(1), 168-174. https://doi.org/10.1177/0092070300281015

Prashar, A. (2017). Adopting PDCA (Plan-Do-Check-Act) cycle for energy optimization in energy-intensive SMEs. Journal of Cleaner Production, 145, 277-293. https://doi.org/10.1016/j.jclepro.2017.01.068

Reichheld, F. F., \& Schefter, P. (2000). E-loyalty: Your secret weapon on the web. Harvard Business Review, 78(4), 105-113.

Rezaei, S., \& Amin, M. (2013). Exploring online repurchase behavioural intention of university students in Malaysia. Journal for Global Business Advancement, 6(2), 92-119. https://doi.org/10.1504/JGBA.2013.053561

Seiders, K., Voss, G. B., Grewal, D., \& Godfrey, A. L. (2005). Do satisfied customers buy more? Examining moderating influences in a retailing context. Journal of Marketing, 69(4), 26-43. https://doi.org/10.1509/jmkg.2005.69.4.26

Statista. (2020). The statistics portal 2018. Retrieved February 2, 2020, from https://www.statista.com/statistics/272314/advertising-spending-in-the-us

Vásquez, F., \& Vera-Martínez, Y. J. (2020). From e-quality and brand perceptions to repurchase: a model to explain purchase behaviour in a web-store. Journal of Theoretical and Applied Electronic Commerce Research, 15(3), 20-35. https://doi.org/10.4067/S0718-18762020000300103

Voss, G. B., Godfrey, A., \& Seiders, K. (2010). How complementarity and substitution alter the customer satisfaction-repurchase link. Journal of Marketing, 74(6), 111-127. https://doi.org/10.1509/jmkg.74.6.111

Webster Jr, F. E. (2000). Understanding the relationships among brands, consumers, and resellers. Journal of the 
Academy of Marketing Science, 28(1), 17-23. https://doi.org/10.1177/0092070300281002

Yaseen, H., Alhusban, M. D., Dingley, K., \& Alhosban, A. (2016). Facilitating e-commerce in Jordan: A qualitative analysis. International Journal of Digital Society, 7(4), 1206-1213. https://doi.org/10.20533/ijds.2040.2570.2016.0148

Zboja, J. J., \& Voorhees, C. M. (2006). The impact of brand trust and satisfaction on retailer repurchase intentions. Journal of Services Marketing, 20, 381-390. https://doi.org/10.1108/08876040610691275

\section{Copyrights}

Copyright for this article is retained by the author, with first publication rights granted to the journal.

This is an open-access article distributed under the terms and conditions of the Creative Commons Attribution license (http://creativecommons.org/licenses/by/4.0/). 